\title{
The Current Status of Forage Soybean
}

\author{
Sovetgul Asekova ${ }^{1}$, J. Grover Shannon ${ }^{2}$, Jeong-Dong Lee ${ }^{1 *}$ \\ ${ }^{1}$ School of Applied Biosciences, Kyungpook National University, Daegu 702-701, Republic of Korea \\ ${ }^{2}$ Division of Plant Sciences, University of Missouri-Delta Center, Portageville, MO 63873, USA
}

\begin{abstract}
Soybeans have a long history as a nutritious hay and silage crop. Early research extensively investigated forage yield, adaptability to various maturity zones, and nutritional values. Evaluation and breeding with diverse soybean accessions continued to optimize soybean forage yield and quality. There is still interest by breeders in developing more desirable forage soybeans, depending on market demand, and the existing interests of crop and livestock producers. In this review, we provide an update compiled from recent publications on the use and development of soybean as a forage crop.
\end{abstract}

Keywords Soybean forage, Wild soybean, Forage quality

\section{INTRODUCTION}

Soybeans are at present estimated to be an ingredient in about two-thirds of all manufactured food products. Production has expanded dramatically in Brazil, Argentina, the USA, and China, these countries being the major soybean producers in the world (Cheeke 2005). Soybean is also very important as an animal feed (Fuller 2004). Soybean originated from Northeastern Asia, including China, Korea, and Japan, and was introduced to Western countries. Soybean was planted as a forage crop in the mid-1800s in the United States (Arny 1926). Hackleman (1924) concluded that soybeans were the best annual nitrogenous seed and hay-producing plant among legumes. Usage of soybeans developed from a feeding source only for ruminants, to also become a main raw material for piglets, and a special forage in fish farming practices. Soybeans were evaluated for forage quality and yield. Crude protein (CP) concentrations of soybean hay generally range from 12 to $14 \%$ for stems, 19 to $20 \%$ for leaves, and 12 to $27 \%$ for pods, depending on the plant's stage of development (Miller et al. 1973). Forage soybean has exhibited good adaptability to various climatic zones, including the semiarid Plains (Nielsen 2011; Nielsen et al.
2010) tropical areas (Crusciol et al. 2012), Mediterranean climates (Acikgoz et al. 2009; Bilgili et al. 2005), and sub-tropical climates (Mislevy et al. 2005; Tubbs \& Gallaher 2010). Forage cultivars with late maturity and harvested at growth stages from R5 (R-reproductive) to R7 (Fehr et al. 1971) were recommended as the optimum scenarios for producing soybean forage. Forage in this production system generally has the best combination of low fiber, high protein content, and digestible energy (Munoz et al. 1981; Hintz \& Alberch 1994; Zhai et al. 2008; Sheaffer et al. 2001; Darmosarkoro et al. 2001: Lee et al. 2014; Açikgöz et al. 2013).

Soybeans provide a high protein and high energy forage crop for livestock. In addition, as a legume it provides additional nitrogen via nitrogen fixation to grasses or cereal crops that are used in a rotation scheme with soybean (Sheaffer \& Seguin 2003; Sunclair \& Vadez 2012; Entz et al. 2002).

This review discusses several key features that should be exploited to meet the future demands for production and variety development of soybean for forage. These topics include the 1) yield and quality of forage soybean by maturity, 2) impact of soybean row spacing and seeding rate on optimum forage production, 3) nutritive value of

Received December 22, 2014; Revised December 26, 2014; Accepted December 27, 2014; Published December 31,2014

*Comesponding author Jeong-Dong Lee, jdlee@knu.ac.kr, Tel: +82-53-950-5709, Fax: +82-53-958-6880 
forage soybean, 4) benefits of intercropping soybeans with other crops, and 5) soybean variety improvement for forage.

\section{Yield and quality of soybean forage by maturity}

Soybean cultivars are classified into 13 maturity groups (MG), ranging from 000 (early maturity) to IX (very late maturity), with varieties in a particular MG planted to utilize and optimize the photoperiod (day length on reproductive behavior), primarily to maximize grain yield. Soybean yield and yield components can be affected by growth habit and planting date (Pederson \& Lauer 2004; Keim et al. 1999).

Soybean is a photoperiod sensitive crop, which means that flowering and seed production are based on length of darkness. Varieties grown for seed are grouped into maturity groups, based on narrow maturity ranges by latitude. However, the best soybean varieties to grow for forage at a particular latitude can be inappropriate for seed production, and vice versa. For example, an older forage-type soybean 'Wisconsin Black' (MG I) of Belgian origin showed the least dry matter yield (up to 50\%) compared with forage and grain-type (MG V-VII) soybeans grown at two Minnesota locations (Sheaffer et al. 2001). The large increase in forage yield and small effect on forage quality associated with growing cultivars of later than normal maturity suggests that cultivars of later maturity, when compared to locally adapted cultivars for seed production, are often the best choice for soybean forage production (Hintz et al. 1992). Ocumpaugh et al. (1981) sod-seeded four soybean cultivars with several MGs (II, III, and V) into grass pasture, and reported a notable advantage in dry matter yield and CP concentration for late-maturing cultivars. Forage soybeans can be harvested a month earlier than conventional grain soybeans. When forage soybeans are produced for seed and/or forage, soybean maturity must be considered.

It is known that growth stage at time of harvest has a greater effect on the yield and quality of forage produced, than agronomic practices of row spacing and planting rate (Acikgoz et al. 2009; Hintz et al. 1992). Typically, harvesting soybean forage during vegetative and early reproductive development results in significantly lower dry matter yields and quality, than harvesting at later reproductive stages. Hintz \& Albrecht (1994) reported that the leaf concentration of grain soybean decreased from $70.8 \%$ at R1 (beginning bloom), to $16.8 \%$ at R7 (beginning maturity). Meanwhile, the stem fraction increased from $29.2 \%$ at R1 to $38.3 \%$ at R5 (beginning seed development), and then declined to $28.3 \%$ at R7, as the pod and seed components increased in weight. Harvest of soybean as a forage should be completed no later than the R7 stage of maturity. Soybean harvested for forage from R6 to R7 maximized both the dry matter yield and forage quality, compared to earlier or later-stage harvesting (Munoz et al. 1983; Hintz et al. 1992; Blount et al. 2003).

Forage cultivars had more leaf and stem yield, and produced little or no grain, depending on harvest date (Darmosarkoro et al. 2001; Sheaffer et al. 2001). In addition, forage cultivars had greater stem dry matter and leaf dry matter accumulation than the grain-type cultivars; however, pod dry matter was greater in the grain type varieties. Darmosarkoro et al. (2001) demonstrated that the later-maturing cultivars had greater potential for vegetative growth, than earlier varieties. For soybean forage to have the best quality, it should be harvested prior to physiological maturity. A two-year study by Sheaffer et al. (2001) compared forage yields from early harvest of grain-type cultivars, to yields of forage-type cultivars harvested late. Yields were similar in one year, while the other year yield forage-type cultivars showed greater forage yields, even though the late-harvested forage types lagged in maturity. These results suggest that if harvested at a similar maturity stage, forage soybeans would generally have superior dry matter yields to the grain soybeans types.

Annual wild soybean (Glycine soja Sieb. and Zucc.), is the progenitor of the cultivated soybean $[G . \max (\mathrm{L}$.) Merr.], and is widely distributed in China, Korea, Japan, and the far eastern regions of Russia. Zhai et al. (2008) reported that on an average, whole plant dry matter for wild soybean lines produced from 2.3 to $6.5 \mathrm{t} \mathrm{ha}^{-1}$, when harvested at different dates. The maximum dry matter yield was 145 days after sowing, which reached between stages of R6 and R7. Recently, Lee et al. (2014) studied wild soybean accessions for forage yield and quality traits. The average dry matter produced by wild accessions ranged from 0.9 to $4.9 \mathrm{tha}^{-1}$. Forage quality characteristics, neutral 
detergent fiber (NDF), acid detergent fiber (ADF), and relative feed value (RFV) were consistent with the other reports investigating typical forage-type and grain-type cultivars.

\section{Row spacing and seed rate impacts}

Several field trials were conducted on row spacing and seeding rates under different environmental conditions, to measure the effect on forage and seed yield. Açikgöz et al. (2009) demonstrated that $\mathrm{CP}$ and oil content of forage type soybeans grown under various row spacings $(20,40,60$, and 80$)$ and seeding rates $(330000,660000,990000$, and 1320000 seeds $^{-1}{ }^{-1}$ ) were not significantly affected when planted in Mediterranean environments. Similar results were observed by Sheaffer et al. (2001) on the quality of total herbage, leaves, and pods evaluated at two row widths ( 76 to $25 \mathrm{~cm}$ ), when planted in two environments at the University of Minnesota. However forage yields were different for narrow and wide rows. Forage yields produced an average dry matter yield of $10.3 \mathrm{t} \mathrm{ha}^{-1}$ for $25 \mathrm{~cm}$ rows, compared to $9.5 \mathrm{t} \mathrm{ha}^{-1}$ for $76 \mathrm{~cm}$ rows (Sheaffer et al. 2001). Likewise, in another study, forage soybeans grown at 25 $\mathrm{cm}$ row spacing produced $35 \%$ more dry matter yield than at $75 \mathrm{~cm}$ row spacing (Açikgöz et al. 2013). Although the total dry matter production was greater for narrow row spacing than wide row spacing, seeding rates from 250000 to 741300 plants ha $^{-1}$ had little effect of forage yield (Hintz et al. 1992). However, Munoz et al. (1983) suggested that

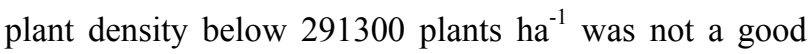
procedure to obtain maximum dry matter accumulation, and concluded that plant densities similar to those used in soybean production also seemed right for forage production. Recently published data by Açikgöz et al. (2009) using a tall robust forage type soybean line '1530' (MG IV) demonstrated that about 30 plants per $\mathrm{m}$ row was optimum to obtain a maximum yield in a $60 \mathrm{~cm}$ row spacing.

\section{Nutritive value of forage soybean}

High-quality forage as determined by animal nutritionists is determined by relative values of $\mathrm{CP}$, crude fat (CF), $\mathrm{NDF}, \mathrm{ADF}, \mathrm{RFV}$, and total digestible nutrients (TDN). Currently, RFV is an important tool in the marketing of forage, and is the only forage quality index used widely in the United States (Moore \& Undersaner 2002). TDN may have been the first measure of available energy to be adopted for routine use by nutritionists, and is used to describe the relative forage quality (RFQ) index. RFQ is an estimate of the voluntary intake of available energy, when forage is fed as the sole source of energy and protein (Moore \& Undersander 2002). NDF and ADF are indicators of dietary energy and intake, especially for ruminant rations. NDF is considered to be the entire fiber fraction of the feed, whereas ADF includes the cellulose and lignin from cell walls, and variable amounts of xylem and other components (Jung 1997). Soybean forage consistently has high protein concentration, due to the unique capacity of soybean to biologically fix $\mathrm{N}$, resulting in a reliable and inexpensive protein source for animal nutrition. The percentage of protein in soybean forage does not decrease as plants advance to maturity, since seeds contain 35 to $40 \%$ protein. Soybean harvested for forage before leaf drop generally has high nutritive value, with higher CP ( 22\%) content and lower digestible dry matter $(71.5 \%)$ than corn or sorghum (Okoli et al. 1984; Sheaffer et al. 1992).

The majority of lipids in forages are their proportion of the plant dry weight decreases as the plant matures (Hawke 1973). The quality characteristic of ether extract (EE) concentration was up to $12.6 \%$ in a soybean cultivar (Hintz et al. 1992), whereas EE content in alfalfa was approximately $2.0 \%$. The reason to mention these characteristics is that a large portion of EE was not so beneficial to ruminant feeding value, yet for lactating dairy cattle, EE can increase milk production (Palmquist \& Jerkins 1980).

Wild soybean ( $G$. soja) is now a popular genetic source for soybean breeders, to improve forage quality and yield. Although wild soybean had lower CF (2.0\%) and CP (17.7\%) concentration than cultivated soybean (5.7 and $21.3 \%$, respectively) at the R6 growth stage, there were no significant differences for neutral detergent fiber, ADF, and RFV among growth stages between cultivated and wild soybean. The NDF was 40.2 and $40.4 \%$, ADF was $26.1 \%$ and $27.5 \%$, and RFV was 161 and 158 at R6 stage for cultivated and wild soybean, respectively (Lee et al. 2014).

Plant parts of the soybean, such as stems, leaflets, and pods, can contribute to dry matter productivity at different harvest maturities. Dry matter yield of soybean forage 
typically increases with advancing maturity; however, changes in forage quality are less consistent. This is due to changes in the proportions of the leaf, stem, and pod fractions, as well as the translocation of nutrients to the grain, and increases in the lipid concentration of the seed (Hanway \& Weber 1971). Increased nutritional value in seeds during maturity stage causes a decline in the forage quality of vegetative portions of the plant. More rapid leaf area development and delayed flowering are options for increasing $\mathrm{N}$ storage, and hence $\mathrm{N}$ fixation activity and crop yield. Genotypes with more rapid vegetative development, particularly rapid leaf area development, are strong candidates for increasing plant $\mathrm{N}$ storage capacity (Sinclair \& Vadez 2012).

Hintz et al. (1994) noticed fiber concentration (NDF, $\mathrm{ADF}$, and $\mathrm{ADL}$ ) on leaf and stem fractions increases with advancing maturity, whereas $\mathrm{CP}$ concentrations declined from R1 to R3, remained constant between R3 and R5, and increased from R5 to R7. Soybean leaves can have a twofold greater $\mathrm{N}$ concentration than stems (Hintz \& Albrecht 1994; Rao et al. 2005). For grazing livestock, CP of soybean leaf (leaf-blade-plus-flowers) and stem (stemplus-petiole) fractions at vegetative growth, were 31.3\% and 12.6\%, respectively (Sheaffer et al. 1992). Protein content of soybean hay generally ranges from 12 to $14 \%$ for stems, 19 to $20 \%$ for leaves, and from a low of 12 to $14 \%$ to a high of 25 to $27 \%$ for pods, depending on the stage of development (Miller et al. 1973). The nutritive values at different maturity stages of soybean plant parts are indicators of high quality alternative forage in summer (hay, silage etc.).

\section{Benefits in intercropping}

Legumes like soybean are not only a high protein and high energy forage crop for livestock, but also have the capability of nitrogen fixation. Therefore, soybean is beneficial to inter crops or succeeding crops in the rotation, such as grasses or cereals (Sheaffer \& Seguin 2008; Sunclair \& Vadez 2012; Entz et al. 2002). Soybean and cowpea planted after barley harvest have the potential to produce forage of high nutritive value and palatability that results in high daily animal weight gains (Sheaffer et al. 1992). However, crops grown in various climatic conditions and environments respond unconventionally, when intercropped. For example, cowpea is far more sensitive to saturated soils than soybean. In a study by Mislevy et al. (2005) the average dry biomass of forage soybean cultivars produced from 5.5 to $7.5 \mathrm{t} \mathrm{ha}^{-1}$ when planted in subtropical environments; whereas under the same conditions, cowpea produced comparable dry biomass $\left(7.2 \mathrm{t} \mathrm{ha}^{-1}\right)$. In their study, poor cowpea forage yield $\left(1.0-0 \mathrm{tha}^{-1}\right)$ was noted when total rainfall exceeded $78 \%$ more precipitation than average. However, soybean had stable growth and forage yield of $5.5 \mathrm{tha}^{-1}$ under saturated soil conditions. The early maturing soybean cultivars (Monsoy 6101, Embrapa 48),
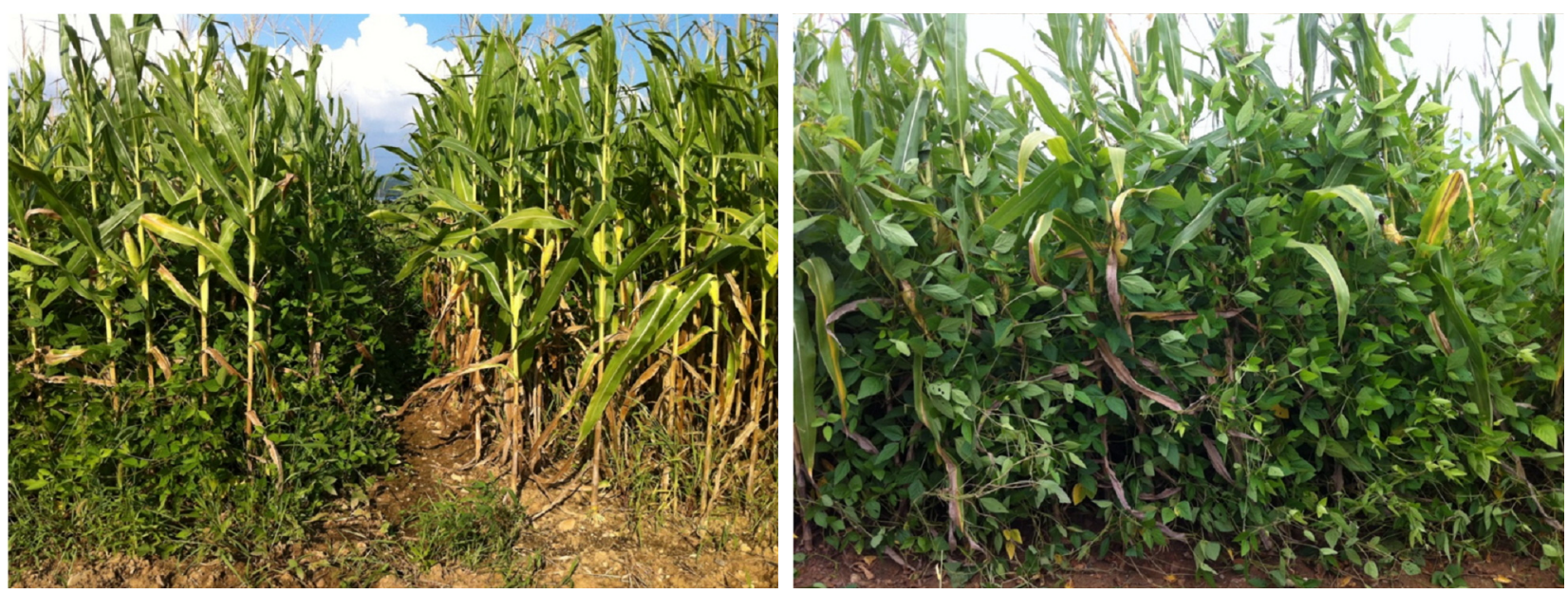

Fig. 1. Comparison of mixed planted between corn and soybean, and corn mono planting at forage harvesting stage. Right picture showing well adapted soybean line under mixed planting with corn. Picture taken from the middle row of a plot (Seo et al. 2014). 
in contrast to normal and late soybean cultivars (BRS 133, Emgopa 313), intercropped with palisade grass, were the best fit for crop-livestock integration in Brazil, with no risk in yield loss in either crop (Crusciol et al. 2012). Recently, Seo et al. (2014) reported the mixed planting of soybean and corn. Three recombinant inbred lines W2, W4, W11 selected from G. soja (PI483463) x G.max (Hutcheson) were intercropped with the forage corn cultivar 'Kwangpyeongok', aimed at producing higher forage yield and quality (Fig. 1). The results showed that the mixed planting of soybean and corn generally produced higher forage yield than mono cropped corn. Also, the $\mathrm{CP}$ and $\mathrm{CP}$ contents were higher with the mixed planting of soybean and corn, compared with mono cropped corn. However dry matter accumulation was lower $\left(4.06 \mathrm{tha}^{-1}\right)$, when soybean was intercropped with forage sorghum [Sorghum bicolor (L.) Moench], higher than $2.3 \mathrm{t} \mathrm{ha}^{-1}$ produced for monocrop soybean (Redfearn et al. 1999).

Winter wheat as forage is often available during winter and early spring. In the north central USA, warm-season grasses are productive only in late spring and early summer, and their quality declines during mid and late summer. Double-cropping soybean as forage after winter wheat, winter rye, and spring barley was practical in the north central USA environment (LeMahieu \& Brinkman 1990). Dry land soybean in a wheat-soybean forage double-crop system in the southern Great Plains in the USA failed to offer any $\mathrm{N}$ benefit to the following winter wheat crop, when grazing or harvest of the soybean was initiated soon after growth stage R5 (MacKown et al. 2007). Use of a forage-type soybean, and extending the growth period before incorporation as a green manure, could increase soybean biomass and the amount of aboveground N, to benefit the following winter wheat crop (Rao et al. 2005). Cultivar selection should be taken into account for a successful soybean management system.

\section{Varietal improvement for forage}

Since soybean was introduced to Western countries as a forage crop, some forage soybean cultivars have been released. Tall forage soybean cultivars 'Derry', 'Donegal', and 'Tyrone' were developed from late maturity groups VI, V, and VII (Devine \& Hatley 1998; Devine et al. 1998a, 1998b). Donegal is adapted to the Northeastern United States, Derry is adapted to the northern Midwest, and Tyrone is adapted to the Southern United States. For different climatic zones, such as Subtropical and Mediterranean environments, these forage cultivars produced DM yields similar to, or higher than grain-type cultivars (Heitholt et al. 2004; Sheaffer et al. 2001; Açikgöz et al. 2013; Darmosarkoro et al. 2001; Nielsen 2011).

F94-2290, a long juvenile genotype, was developed by the University of Florida Agricultural Experiment Station. It is of MG VIII maturity, and described as a well-adapted germplasm for late plantings, where it has superior seed and foliage yield, compared with soybean cultivars lacking the long juvenile trait (Blount et al. 2003). Hintz et al. (1992) reported on cultivars with normal and late maturity, and growing cultivars of later maturity would be the best to improve forage yield and forage quality. Later-maturing cultivars 'Hutcheson' and 'Biloxi' showed the most potential for forage vegetative growth (Darmosarkoro et al. 2001).

Wild soybean (G. soja Sieb. \& Zucc.), known as the direct progenitor of soybean, has provided useful genes for soybean improvement (Hymowitz \& Singh 1987; Fehr et al. 1971; Hongrun \& Kiang 1993; Wang et al. 2001). In Asia, wild soybean has been used as forage for livestock. Wild soybeans have good nutritional value and thin stems, which may elevate feeding efficiency in livestock, compared to cultivated soybean. Even though wild soybean has several benefits for feed, it has unfavorable characters, such as hard seed, shattering, and a viny growth habit.

There is a progress to develop forage soybeans from interspecific crosses between $G$. $\max$ and $G$. soja. A recombinant inbred population was developed from a cross of PI486463 (G. soja) x Hutcheson (G. max). Promising lines with high yield, no hard seed, no shattering, and thinner stems than cultivated soybean were reported by Lee et al. (2014a). Lee et al. (2014a) evaluated 25 lines from PI483463 $\times$ Hutcheson or S-100 (G. max $) \times$ PI483463, and four common seed-type cultivars, Bosug (Oh et al. 2003), Pungsannamul (Suh et al. 1997), Taekwang, and Hutcheson, for forage yield and quality at the R6 growth stage. Hutcheson had the highest forage yield among seed-type soybeans, with $24.7 \mathrm{t} / \mathrm{ha}$ in fresh weight $(\mathrm{FW})$, and $6.6 \mathrm{t} / \mathrm{ha}$ in dry matter. Five selected lines (W02, W06, W11, W13, 
and W18) had similar forage yields, compared to Hutcheson. Generally, the 25 selected lines derived from G. soja $\times G$. max had thinner main stems and branches, which resulted in a more edible forage than cultivated soybeans. When the selected lines were evaluated for their feed quality based on forage grade by the American Forage and Grassland Council, 23 lines had more than 19\% CP; 9 lines had a NDF below 40\%; 23 lines had an ADF below 31\%; 24 lines had a digestible dry matter of more than $65 \% ; 13$ lines had a dry matter intake of more than $3.0 \%$, and 17 lines had an RFV higher than 151, or equivalent to prime grade. All of the 25 G. $\max \times$ G. soja inbred lines were equivalent to Grade 1 .

Intercrossing the two species ( $G$. soja $\times$ G. max) then selecting forage type soybeans appears to be a promising method to develop high yield, high protein, low fat, and high energy forage. Forage breeding research in soybeans should also include resistance and tolerance to biotic and abiotic stresses, and should include other desirable attributes that are found in seed type cultivars.

\section{CONCLUSIONS}

There is renewed interest in developing soybean cultivars with improved forage value, versus seed type cultivars. Generally, tall late maturing cultivars are the best options for growing soybean for forage. Forage yields have been greatest when planted in narrow rows. However, plant population within rows has had little effect on forage yield. Because soybean is a legume and fixes nitrogen, it is a reliable source of $\mathrm{CP}$ as a livestock feed. In addition, seeds are high in edible protein and oil, which adds more forage value to soybean. The nitrogen fixing ability makes soybean a valuable crop for intercropping, and for use in rotations, to add residual nitrogen to crops after soybeans. Crosses between cultivated (G. max) and wild soybean ( $G$. soja) have been implemented to improve the forage quality of soybeans. Forage value of lines from cultivated by wild soybean crosses show that these lines have thinner stems and similar nutrient values, compared to forage derived from cultivated soybeans. Since there has been little study of the genetic factors related to soybean forage, further research is needed to improve the forage yield and quality characteristics. Soybean forage cultivars need improved stress tolerance, and $\mathrm{CP}$ and oil concentration, to broaden soybean use as a feed for livestock production.

\section{ACKNOWLEDGEMENTS}

This research was supported by the Bio-industry Technology Development Program (Grant No. 314024-3), of the Ministry of Agriculture, Food and Rural Affairs, Republic of Korea.

\section{REFERENCES}

Arny AC. 1926. The influence of time of cutting on the quality of crops. Agron. J. 18: 684-703.

Acikgoz E, Sincik M, Karasu A, Tongel O, Wietgrefe G, Bilgili U, Oz M, Albayrak S, Turan ZM, Goksoy AT. 2009. Forage soybean production for seed in mediterranean environments. Field Crop. Res. 110: 213-218.

Açikgöz E, Sincik M, Wietgrefe G, Sürmen M, Çeçen S, Yavuz T, Erdurmuş C, Göksoy AT. 2013. Dry matter accumulation and forage quality characteristics of different soybean genotypes. Turk. J. Agric. For. 37: 22-32.

AlZahal O, Or-Rashid MM, Greenwood SL, McBride BW. 2010. Effect of subacute ruminal acidosis on milk fat concentration, yield and fatty acid profile of dairy cows receiving soybean oil. J. Dairy Res. 77: 376-384.

Bilgili U, Sincik M, Goksoy AT, Turan ZM, Acikgoz E. 2005. Forage and grain yield performances of soybean lines. Centr. Europ. Agricult. 6: 397-402.

Blount AR, Barnett RD, Hinson K, Kinloch RA. 2003. Registration of F94-2290 long juvenile soybean germplasm. Crop Sci. 43: 1890-1891.

Cheeke PR. 2005. Applied animal nutrition: Feeds and feeding. Pearson Prentice Hall.

Crusciol CAC, Mateus GP, Nascente AS, Martins PO, Borghi E, Pariz CM. 2012. An innovative crop-forage intercrop system: Early cycle soybean cultivars and palisadegrass. Agron. J. 104: 1085-1095.

Darmosarkoro W, Harbur MM, Buxton DR, Moore KJ, Devine TE, Anderson IC. 2001. Growth, development, and yield of soybean lines developed for forage. Agron. J. 
93: 1028-1034.

Devine TE, Hatley EO, Stamer DE. 1998. Registration of 'Derry' forage soybean. Crop Sci. 38: 1719.

Devine TE, Hatley EO. 1998a. Registration of 'Donegal' forage soybean. Crop Sci. 38: 1719-1720.

Devine TE, Hatley EO, Stamer DE. 1998b. Registration of 'Tyrone' forage soybean. Crop Sci. 38: 1720.

Entz MH, Baron VS, Carr PM, Meyer DW, Smith Jr. SR, McCaughey WP. 2002. Potential of forages to diversify cropping systems in the northern Great Plains. Agron. J. 94: 240-250.

Fehr WR, Caviness CE, Burmood DT, Pennington JS. 1971. Stage of development descriptions for soybeans, Glycine $\max ($ L.) Merrill. Crop Sci. 11: 929-931.

Fuller MF. 2004. The Encyclopedia of Farm Animal Nutrition. CABI Publishing. Cambridge, MA 02139, USA.

Hanway JJ, Weber CR. 1971. Dry matter accumulation in eight soybean [Glycine $\max (\mathrm{L}$.) Merill] plants. Agron. J. 63: 406-408.

Hacklman JC. 1924. The future of the soybean as a forage crop. Paper read as part of the symposium on November 12, 1923 "The Forage Problem" at the meeting of the Society held in Chicago.

Hawke JC. 1973. Lipids. In: Butler GW and Bailey RW (ed.). Chemistry and Biochemistry of Herbage. Vol. 1 p. 213231. Academic Press Inc. NY.

Heitholt JJ, Kee D, Farr JB, Read JC, Metz S, MacKown CT. 2004. Forage from soybean provides an alternative to its poor grain yield in the southern Great Plains. Online. Crop Management doi:10.1094/CM-2004-0406-01-RS.

Hintz RW, Albrecht KA, Oplinger ES. 1992. Yield and quality of soybean forage as affected by cultivar and management practices. Agron. J. 84: 795-798.

Hintz RW, Albrecht KA. 1994. Dry matter partitioning and forage nutritive value of soybean plant components. Agron. J. 86: 59-62.

Hongrun Y, Kiang YT. 1993. Genetic variation in South Korean natural populations of wild soybean (Glycine soja). Euphytica 68: 213-221.

Hymowitz T, Singh RJ. 1987. Taxonomy and speciation. In: Wilcox JR (ed.). Soybeans: Improvement, production and uses. Agronomy Monograph no. 16. 2nd ed. p.23- 48. ASA and CSSA publications, Madison, WI.

Jung HJG. 1997. Analysis of forage fiber and cell walls in ruminant nutrition. J. Nutr. 127: 810S-813S.
Keim KR, Eren A, Edwards LH. 1999. Long-term study of planting date effects on seed yield in soybean. J. Prod. Agric. 12: 288-292.

Lee EJ, Choi HJ, Shin DH, Kwon CH, Shannon JG, Lee JD. 2014. Evaluation of forage yield and quality in wild soybeans (Glycine soja Sieb. and Zucc.). Plant Breed. Biotech. 2(1): 71-79.

Lee EJ, Choi HJ, Shin DH, Kwon CH, Shannon JG, Lee JD. 2014a. Evaluation of forage yield and quality for the accessions derived from inter-specific cross between wild and cultivated soybeans. Korean J. Breed. Sci. 46: 66-77.

LeMahieu PJ, Brinkman MA. 1990. Double-cropping soybean after harvesting small grains as forage in the North Central USA. J. Prod. Agric. 3: 385-389.

MacKown CT, Heitholt JJ, Rao SC. 2007. Agronomic feasibility of a continuous double crop of winter wheat and soybean forage in the southern Great Plains. Crop Sci. 47: 1652-1660.

Major DJ, Johnson DR, Tanner JW, Anderson IC. 1975. Effects of day length and temperature on soybean development. Crop Sci. 15: 174-179.

Miller MD, Edwards RT, Williams WA. 1973. Soybean for forage and green manure. In: Beard BH and Knowles PF (ed.). Soybean research in California. p. 60-66. California Agric. Exp. Stn. Bull. 862.

Mislevy P, Blount AR, Martin FG, Scully BT. 2005. Soybean and clay cowpea grown for forage production in the subtropics. Online. Crop Management doi:10.1094/CM2005-0926-01-RS.

Moore JE, Undersander DJ. 2002. Relative forage quality: An alternative to relative feed value and quality index. Proc. 13th Annual Florida Ruminant Nutrition Symposium. Vol. 32. 2002. Available at: https://docs.google.com/ viewer?url=http $\% 3 \mathrm{~A} \% 2 \mathrm{~F} \% 2 \mathrm{Fdairy}$.ifas.ufl.edu $\% 2 \mathrm{FRN}$ S\%F2002\%2Fmoore.pdf

Munoz AE, Holt EC, Weaver RW. 1983. Yield and quality of soybean hay as influenced by stage of growth and plant density. Agron. J. 75: 147-148.

Nielsen DC. 2011. Forage soybean yield and quality response to water use. Field Crop. Res.124: 400-407.

Nielsen DC. Vigil MF, Benjamin JG. 2010. Evaluating decision rules for dryland rotation crop selection. Field Crop. Res. 120, 254-261.

Ocumpaugh WR, Matches AG, Luedders VD. 1981. Sod-seeded soybeans for forage. Agron. J. 73: 571-574. 
Oh YJ, Kim KH, Suh SK, Park HK, Lee MJ, Kim HS, Kim YJ, Kim SD, Lee SH. 2003. A new soybean variety for sprout with small seed size resistance and high yielding "Bosug". Kor. J. Breed. Sci. 37: 109-110.

Okoli PS, Drolsom PN, Scholl JM. 1983. Forage production and weed control in a double-cropping program. Agron. J. 76: 363-366.

Palmquist DL, Jerkins TC. 1980. Fat in lactation rations: Review. J. Dairy Sci. 63: 1-14.

Pedersen P, Lauer JG. 2004. Response of soybean yield components to management system and planting date. Agron. J. 96: 1372-1381.

Rao SC, Mayeux HS, Northup BK. 2005. Performance of forage soybean in the southern Great Plains. Crop Sci. 5: 1973-1977.

Redfearn DD, Buxton DR, Devine TE. 1999. Sorghum intercropping effects on yield, morphology, and quality of forage soybean. Crop Sci. 39: 1380-1384.

Seo JD, Chae JH, Park JH, Kim MS, Kwon CH, Lee JD. 2014. Yield and quality of forage produced by mixed planting of soybean and corn. Current Research on Agric. \& Life Sci. 32: 105-109.

Sheaffer CC, Marten GC, Jordan RM, Ristau EA. 1992. Sheep performance during grazing of annual forages in a double cropping system. J. Prod. Agric. 5: 33-37.

Sheaffer CC, Orf JH, Devine TE, Jewett JG. 2001. Yield and quality of forage soybean. Agron. J. 93: 99-106.

Sheaffer CC, Seguin P. 2008. Forage legumes for sustainable cropping systems. J. Crop Product. 8: 1-2. doi: 10.1300/ J144v08n01_08.

Sinclair TR, Vadez V. 2012. The future of grain legumes in cropping systems. Crop Pasture Sci. 63: 501-512.

Suh SK, Kim HS, Oh YJ, Kim KH, Cho SK, Kim YJ, Kim SD, Park HK, Park MS, Cho SY. 1997. A new soybean variety for sprout with small seed and high yielding “Pungsan-namulkong”. Kor. J. Breed. Sci. 29: 503.

Tubbs RS, Gallaher RN. 2010. Row spacing and cultivar effects on yield and forage quality of fall-grown soybean. Online. Crop Management doi:10.1094/CM-2010-031601-RS.

Undersander D, Jarek K, Anderson T, Schneider N, Milligan L. 2007. A guide to making soybean silage. Online. Forage and Grazinglands. doi:10.1094/FG-2007-011901-MG.

Wang D, Diers BW, Arelli PR, Shoemaker RC. 2001. Loci underlying resistance to Race 3 of soybean cyst nematode in Glycine soja plant introduction 468916. Theor. Appl. Genet. 103: 561-566.

Zhai G, Shen Y, Zhai Y, Liu X, Jiang H. 2008. Forage yield performance and nutritive value of selected wild soybean ecotypes. Can. J. Plant Sci. 88: 465-472. 